\title{
Analisis muatan literasi statistika dalam buku teks matematika Kurikulum 2013
}

\author{
Ezra Putranda Setiawan ${ }^{1^{*}}$ \\ ${ }^{1}$ Department of Mathematics Education, Universitas Negeri Yogyakarta, Indonesia \\ * Corresponding Author. E-mail: ezra.ps@uny.ac.id
}

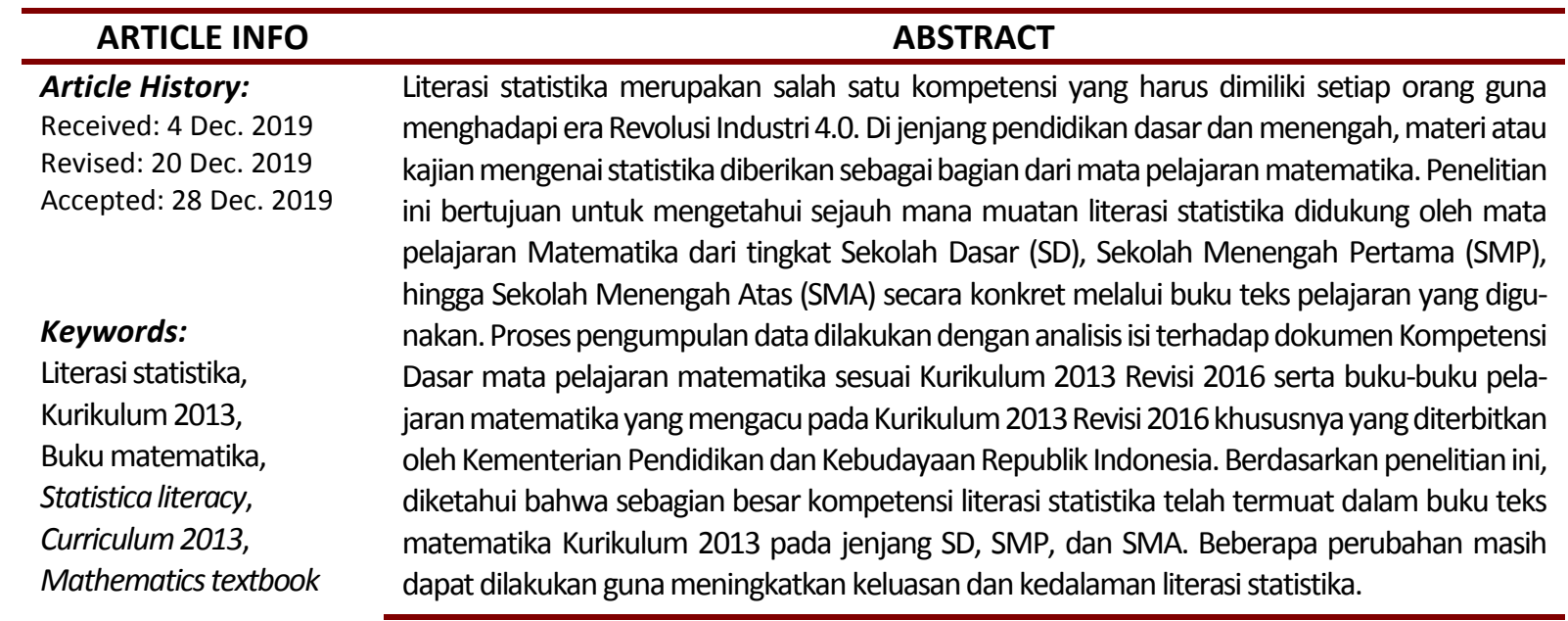

Statistical literacy was one of the competencies that must be mastered by everyone to face the 4.0 Industrial Revolution era. At the level of primary and secondary education, statistics was studied as a part of the mathematics subject. In this research. We examine the extent to which statistical Literacy contents were supported by Mathematics subjects from the Elementary School (SD) level, Junior High School (SMP) level, to the Senior High School (SMA) level. This research focused on the textbooks used in the learning process. The data were collected by analyzing the contents of the mathematics curriculum document (following the Curriculum 2013 Revision Edition of 2016) as well as mathematics textbooks referring to the Curriculum 2013 Revision Edition of 2016 especially books published by the Ministry of Education and Culture of the Republic of Indonesia. Based on this research, it is known that the majority of statistical literacy competencies have been supported by the Curriculum 2013 mathematics textbook at SD, SMP, and SMA level. Some improvements could still be made to increase the breadth and depth of statistical literacy.

SCAN ME

This is an open access article under the CC-BY-SA license

\section{How to Cite:}

Setiawan, E. P. (2019). Analisis muatan literasi statistika dalam buku teks matematika Kurikulum 2013. PYTHAGORAS: Jurnal Pendidikan Matematika, 14(2), 163-177. doi: https://doi.org/10.21831/pg.v14i2.28558

https://doi.org/10.21831/pg.v14i2.28558

\section{PENDAHULUAN}

Dewasa ini, Indonesia dan berbagai negara di seluruh dunia sedang menghadapi Revolusi Industri 4.0 yang ditandai dengan pesatnya perkembangan teknologi sensor, keterhubungan, serta ketersediaan data pada saat bersamaan. Perkembangan-perkembangan inilah yang mendasari munculnya era baru terkait penggunaan data, yakni era big data. Mengacu pada Yaqoob et al. (2018), big data dicirikan setidaknya oleh 5V, yakni volume (ukuran data), velocity (kecepatan masuk dan keluarnya data), variety (keberagaman bentuk dan sumber data), veracity (sifat data yang tidak lengkap dan tidak selalu dapat dipercaya), serta value (nilai informasi yang terkandung pada data). Tercatat bahwa volume data di dunia tumbuh hingga sekitar 40\% per tahun, bahkan 50\% mulai tahun 2020 
(Waal-Montgomery, 2015). Dari segi nilai ekonomis, Khan et al. (2014) mencatat nilai pasar big data pada tahun 2010 mencapai sekitar \$3,2 milyar, dan diprediksi akan meningkat hingga \$16,9 miliar pada tahun 2014.

Pada mulanya, teknologi big data hanya berkaitan dengan pengumpulan informasi dari website, yang sering disebut sebagai web mining (Lee, 2017). Dewasa ini, big data tidak dapat dilepaskan dari Internet of Things (IoT) yakni kumpulan teknologi yang terdiri dari berbagai perangkat atau sensor unik dengan kemampuan untuk mengirimkan dan menggabungkan data melalui jaringan internet, bahkan tanpa bantuan manusia. Teknologi loT telah dipergunakan dalam berbagai bidang, di antaranya perkantoran (smart office), perdagangan (smart retail), pengelolaan kota (smart city), pengelolaan perkebunan atau hutan (smart forest), dan lain-lain (Gubbi, Buyya, Marusic, \& Palaniswami, 2013). Mengingat banyaknya data yang terkumpul melalui teknologi loT, teknologi big data juga dipergunakan dalam berbagai bidang kehidupan.

Untuk dapat memanfaatkan big data dengan baik, diperlukan dua kompetensi utama. Kompetensi pertama berkaitan dengan kemampuan menggunakan program-program komputer, mengingat hampir semua proses pengolahan big data dilakukan dengan bantuan komputer. Kompetensi berikutnya yang tidak kalah penting adalah kemampuan untuk mengolah, menganalisis, membaca, serta menggunakan data yang telah dikumpulkan untuk mengambil simpulan dan tindakan yang tepat. Tanpa kompetensi yang kedua, data yang ada tidak memberikan manfaat apa-apa.

Kompetensi untuk mengolah, menganalisis, membaca, serta menggunakan data untuk mengambil simpulan berkaitan erat dengan literasi statistika. Menurut Schield (1999), literasi statistika merupakan kompetensi, yakni kemampuan berpikir kritis tentang statistika. Ben-Zvi dan Garfield (2004) mendefinisikan literasi statistika sebagai kemampuan dasar dan penting yang digunakan untuk memahami informasi statistik atau hasil penelitian, yang meliputi kemampuan mengorganisasi data, mengkonstruksi dan menyajikan tabel, serta bekerja dengan berbagai bentuk representasi data. Literasi statistika juga mencakup pemahaman berbagai konsep, istilah, dan lambang, serta pemahaman atas probabilitas (peluang) sebagai suatu ukuran ketidakpastian. Dalam pengertian yang lebih luas, Gal (2002) menyebutkan bahwa literasi statistika berkaitan dengan dua komponen yang saling berkaitan, yakni (1) kemampuan seseorang untuk menginterpretasikan dan mengevaluasi informasi statistika secara kritis, pendapat/argumen terkait data, atau peristiwa acak (stochastic phenomena) yang terjadi dalam berbagai konteks secara relevan, dan (2) kemampuan seseorang untuk mendiskusikan atau mengkomunikasikan reaksi mereka terhadap informasi statistika tersebut, misalnya pemahaman terhadap maksud dari informasi, opini terkait dampak suatu informasi, atau persetujuan terhadap simpulan yang diberikan berdasarkan data.

Mengingat pentingnya literasi statistika, Ridgway, Nicholson, dan McCusker (2011) menyatakan bahwa diperlukan adanya ruang dalam kurikulum untuk "reasoning from evidence in realistic situation" yang dilandasi ilmu statistika. Sharma (2017) menyebutkan bahwa beberapa organisasi profesional guru-guru matematika di Amerika Serikat dan Selandia Baru memberikan dukungan kritis terhadap pembelajaran statistika. Ridgway et al. (2011) juga menyebutkan bahwa di Selandia Baru, kurikulum matematika telah memuat tiga unsur terkait literasi statistika, yakni investigasi statistik, interpretasi laporan statistika, dan eksplorasi probabilitas. Schield (2004) memberikan panduan penyusunan kurikulum untuk mendukung literasi statistika, di antaranya kurikulum harus berdasarkan pada data dalam konteksnya, memberikan motivasi kepada para siswa untuk mempelajari statistika, berdasar pada situasi sehari-hari yang dihadapi siswa, serta beberapa kriteria lainnya.

Di Indonesia, penelitian terkait literasi statistika masih sangat terbatas. Hafiyusholeh (2015) menulis artikel tinjauan pustaka atau studi literatur mengenai literasi statistik dan urgensinya bagi siswa. Kusmanto, Nishfani, dan Akbar (2017) menganalisis tingkat kemampuan literasi statistik siswa Sekolah Menengah Atas (SMA) sederajat di Kota Cirebon menggunakan tes yang merujuk pada Assesesment Resource Tools for Improving Statistical Thinking (ARTIST) dan Comprehensive Assessment of Outcomes in a First Statistics Course (CAOS). Penelitian ini menunjukkan bahwa kemampuan literasi statistik siswa berada pada tingkat sedang. Pada tahun 2018, terdapat sejumlah publikasi terkait literasi statistika di Indonesia. Maryati dan Priatna (2018) menyebutkan bahwa kemampuan literasi statistik siswa Madrasah Tsanawiyah di Garut dalam materi statistika masih berada pada kategori rendah. Tiro (2018) menyusun artikel berjudul "Strategi Aksi Gerakan Nasional Literasi Statistika di Indonesia", dengan merujuk pada kesuksesan Irlandia dan Republik Malta dalam mendorong literasi statistika masyarakatnya. Yuniawatika (2018) menekankan kembali pentingnya literasi statistika bagi siswa. Wildani, Triyana, dan Mahmudah (2019) mengukur literasi statistika siswa SMPN 1 Gresik menggunakan hasil adaptasi soal-soal PISA, dan mendapatkan hasil tingkat literasi yang cukup. 
Uraian sebelumnya menunjukkan bahwa sejauh ini upaya pengukuran literasi statistika masih memberikan hasil yang kurang menggembirakan. Diperlukan upaya untuk meningkatkan literasi statistika serta memperluas cakupan penelitian guna memetakan literasi statistika pelajar di Indonesia pada berbagai jenjang. Sejauh ini, Kementerian Pendidikan dan Kebudayaan Republik Indonesia telah mencanangkan gerakan literasi nasional sebagai induk dari gerakan literasi sekolah yang mencakup literasi baca tulis, literasi numerasi, literasi sains, literasi finansial, literasi digital, serta literasi budaya dan kewarganegaraan. Terlihat bahwa literasi statistika belum menjadi fokus gerakan literasi nasional maupun gerakan literasi nasional.

Hingga saat ini, berbagai hal terkait penyajian data dan statistika telah menjadi bagian dari mata pelajaran matematika di jenjang SD, SMP, hingga SMA. Oleh karena itu, masuk akal bila pengembangan literasi statistika pada pelajar dapat dilakukan melalui pembelajaran matematika. Diperlukan penelitian untuk mengungkap sejauh mana kompetensi matematika pada kurikulum pendidikan dasar dan menengah dapat mendukung pengembangan kemampuan literasi statistika. Lebih jauh, perlu dicermati pula apakah buku teks matematika sebagai salah satu bahan ajar yang digunakan telah mendukung kemampuan literasi statistika. Buku teks merupakan salah satu elemen kunci guna meningkatkan efektivitas pembelajaran (Macyntre \& Hamilton, 2010). Buku teks bahkan dipandang lebih dekat dengan kondisi kelas secara nyata dibandingkan kurikulum nasional (Howson, 1995). Valverde, Bianchi, Wolfe, Schmidt, dan Houang (2002) menyebutkan bahwa buku teks merupakan upaya translasi gagasan abstrak dalam kurikulum menjadi tindakan yang dapat dilakukan guru dan murid di kelas.

Walaupun telah ada banyak penelitian terkait buku teks matematika di Indonesia, khususnya untuk bukubuku pada Kurikulum 2013 (misalnya Ramda, 2017; Rizkianto \& Santosa, 2017; Utari \& Hartono, 2019), namun belum dijumpai penelitian yang secara khusus mengkaji kesesuaian buku teks matematika dengan kompetensi literasi statistika. Dengan demikian, penelitian ini bertujuan untuk mengetahui muatan literasi statistika dalam buku teks matematika Kurikulum 2013.

\section{METODE}

Penelitian ini dilakukan dengan metode deskriptif kualitatif, yakni dengan cara mendeskripsikan informasiinformasi yang diperoleh dalam bentuk non-numerik. Proses pengumpulan data dilakukan menggunakan analisis isi (content analysis), yakni pemeriksaan secara sistematis dan mendalam terhadap isi dari suatu bahan tertentu guna mengidentifikasi pola, tema, maupun bias (Leedy \& Ormrod, 2015). Bahan-bahan tertulis yang digunakan dalam penelitian ini terdiri dari dua kelompok, yakni dokumen naskah Kurikulum 2013 serta buku-buku pelajaran matematika sesuai Kurikulum 2013.

Langkah-langkah pengumpulan data yang dilakukan dalam penelitian ini adalah sebagai berikut.

1) Analisis dokumen Kurikulum 2013.

Analisis dokumen Kurikulum 2013 dilakukan untuk mengidentifikasi sebaran kompetensi dasar yang berkaitan dengan literasi statistika, khususnya dalam mata pelajaran matematika. Dokumen yang dianalisis adalah Peraturan Menteri Pendidikan dan Kebudayaan Republik Indonesia Nomor 37 Tahun 2018 tentang Perubahan atas Peraturan Menteri Pendidikan dan Kebudayaan Nomor 24 tahun 2016 tentang Kompetensi Inti dan Kompetensi Dasar Pelajaran pada Kurikulum 2013 pada Pendidikan Dasar dan Pendidikan Menengah.

2) Pemilihan buku teks matematika.

Dalam penelitian ini digunakan buku-buku teks Kurikulum 2013 revisi 2016 terbitan Pusat Perbukuan Kementerian Pendidikan dan Kebudayaan Republik Indonesia, mengingat buku-buku ini digunakan secara luas di berbagai sekolah. Apabila untuk suatu jenjang tidak tersedia buku teks terbitan Pusat Perbukuan Kementerian Pendidikan dan Kebudayaan Republik Indonesia, diambil dua buku teks dari penerbit lain yang telah memperoleh pengesahan untuk digunakan di jenjang Pendidikan Dasar dan Menengah oleh Direktur Jenderal Pendidikan Dasar dan Menengah, Kementerian Pendidikan dan Kebudayaan Republik Indonesia. Rincian mengenai buku teks Matematika yang terpilih disajikan pada bagian Hasil dan Pembahasan.

3) Analisis isi buku teks matematika

Analisis buku teks matematika dilakukan dengan cara melakukan pembacaan dan pencatatan secara cermat. Pertama, peneliti mencermati daftar isi buku yang terpilih pada langkah 2 untuk menentukan bab dalam buku tersebut yang memuat kompetensi inti terkait literasi statistika, sebagaimana telah diidentifikasi pada langkah 1. Selanjutnya, peneliti melakukan pembacaan setiap paragraf dalam bab tersebut dan mencatat materi serta pengalaman belajar yang tersaji dalam bab tersebut. Catatan yang diperoleh kemudian diorganisasikan berdasar kriteria literasi statistika dari beberapa ahli. 
Instrumen utama dalam penelitian analisis isi tidak lain adalah peneliti sendiri. Guna memudahkan organisasi dan kategorisasi data, peneliti menggunakan sejumlah kriteria literasi Statistika yang berdasar pada beberapa literatur berikut.

1) Model literasi statistika oleh Gal (2002).

Menurut Gal (2002), literasi statistika terdiri dari komponen pengetahuan (knowledge) dan komponen sikap (dispositional). Komponen pengetahuan terdiri dari lima unsur, yakni kemampuan literasi (literacy skills), pengetahuan statistika (statistical knowledge), pengetahuan matematika (mathematical knowledge), pengetahuan konteks (context knowledge), dan pertanyaan kritis (critical question). Kelima unsur tersebut dirangkum dalam lima kompetensi, yaitu (1) mengetahui alasan dibutuhkannya data dan cara memperoleh data (knowing why data are needed and how data can be produced); (2) mengenal istilah dasar dan gagasan terkait statistika deskriptif (familiarity with basic terms and ideas related to descriptive statistics); (3) mengenal istilah dasar dan gagasan terkait penyajian grafik dan tabel (familiarity with basic terms and ideas related to graphical and tabular displays); (4) pemahaman konsep dasar probabilitas (understanding basic notions of probability); dan (5) mengetahui bagaimana simpulan statistika atau inferensi dapat diperoleh (knowing how statistical conclusions or inferences are reached).

2) Model tingkatan literasi statistika oleh Watson dan Callingham (2003)

Model pengukuran literasi statistika ini dikembangkan oleh Watson dan Callingham sejak tahun 2003. Dalam model ini, terdapat enam level, dengan level lebih tinggi menunjukkan peningkatan pengetahuan terkait prosedur statistika, pemahaman terkait adanya variasi dan konteks, serta peningkatan kemampuan berpikir kritis terkait pengambilan keputusan dengan mempertimbangkan adanya ketidakpastian. Keenam level tersebut, dalam versi terbaru, dapat dilihat pada Tabel 1.

Tabel 1. Tingkatan Literasi Statistika (Watson \& Callingham, 2003)

\begin{tabular}{|c|c|c|}
\hline Level & Nama & Karakteristik \\
\hline 6 & $\begin{array}{l}\text { Kritis- } \\
\text { matematis }\end{array}$ & $\begin{array}{l}\text { Penugasan dan pertanyaan kritis dalam konteks, menggunakan penalaran proporsio- } \\
\text { nal dalam konteks media atau peluang, menunjukkan apresiasi terhadap perlunya } \\
\text { ketidakpastian dalam prediksi, serta menginterpretasi aspek bahasa secara halus. }\end{array}$ \\
\hline 5 & Kritis & $\begin{array}{l}\text { Penugasan dan pertanyaan kritis dalam konteks familiar maupun tak familiar, yang } \\
\text { tidak melibatkan penalaran proporsional, namun melibatkan penggunaan istilah yang } \\
\text { sesuai, interpretasi peluang secara kualitatif, dan apresiasi terhadap variasi. }\end{array}$ \\
\hline 4 & $\begin{array}{l}\text { Konsisten non } \\
\text { kritis }\end{array}$ & $\begin{array}{l}\text { Penugasan tepat namun tidak kritis, sesuai konteks, memuat berbagai aspek penggu- } \\
\text { naan istilah, pengenalan adanya variasi dalam konsep peluang serta perhitungan } \\
\text { statistika terkait rata-rata, peluang sederhana, dan sifat-sifat atau karakteristik grafik. }\end{array}$ \\
\hline 3 & Inkonsisten & $\begin{array}{l}\text { Penugasan selektif dengan konteks dalam bentuk suportif, pengenalan contoh sim- } \\
\text { pulan yang sesuai namun tidak memuat pertimbangan statistika atau lebih bersifat } \\
\text { kualitatif dalam penggunaan gagasan statistika. }\end{array}$ \\
\hline 2 & Informal & $\begin{array}{l}\text { Penugasan sederhana dengan konteks intuitif dan bersifat non statistik, hanya memuat } \\
\text { satu unsur istilah atau kondisi kompleks, serta tabel, diagram, atau perhitungan } \\
\text { peluang yang dapat diselesaikan/dipahami dalam satu langkah. }\end{array}$ \\
\hline 1 & $\begin{array}{l}\text { Idiosinkratik/ } \\
\text { pribadi }\end{array}$ & $\begin{array}{l}\text { Penugasan bersifat pribadi dengan konteks, menggunakan istilah secara berulang, } \\
\text { kemampuan matematis dasar terkait dengan pencacahan dan membaca nilai sel } \\
\text { dalam suatu tabel. }\end{array}$ \\
\hline
\end{tabular}

3) Model perkembangan penalaran statistika menurut Jones et al. (2000)

Jones et al. (2000) membedakan kemampuan penalaran statistika dalam empat tingkat, yakni pribadi/ idiosinkratik, translasional, kuantitatif, dan analitik. Terdapat empat proses penalaran statistika yang menjadi fokus, yakni (1) mendeskripsikan data: menunjukkan perhatian pada penyajian data, menentukan unit data; (2) mengorganisasikan data: mengelompokkan data, meringkas data menjadi nilai tengahnya, dan mendeskripsikan sebaran data; (3) merepresentasikan data: melengkapi atau menyusun sajian data untuk suatu kelompok data dan mengevaluasi efektivitas sajian data; (4) analisis dan interpretasi data.

Dari keempat proses tersebut, analisis dan interpretasi data dipandang paling penting dan menjadi inti dari penalaran statistika. Oleh karena itu, Jones et al. (2000) dan Mooney (2002) menyusun acuan tingkat kemampuan 
analisis dan interpretasi data untuk siswa jenjang pendidikan dasar (elementary school) dan jenjang pendidikan menengah (middle school) sebagaimana tercantum pada Tabel 2.

Tabel 2. Kompetensi Analisis dan Interpretasi Data (Jones \& Thornton, 2005)

\begin{tabular}{|c|c|c|c|c|}
\hline Jenjang & Level 1 & Level 2 & Level 3 & Level 4 \\
\hline \multirow{4}{*}{$\begin{array}{l}\text { Pendidikan } \\
\text { Dasar }\end{array}$} & \multicolumn{4}{|c|}{ Membaca data (reading between the data): } \\
\hline & $\begin{array}{l}\text { Memberikan respon } \\
\text { invalid ketika dimin- } \\
\text { ta membandingkan } \\
\text { data. }\end{array}$ & $\begin{array}{l}\text { Membandingkan } \\
\text { satu atau lebih data } \\
\text { namun tidak melihat } \\
\text { tren keseluruhan. }\end{array}$ & $\begin{array}{l}\text { Membandingkan } \\
\text { data lokal dan global } \\
\text { namun tidak melihat } \\
\text { hubungannya. }\end{array}$ & $\begin{array}{l}\text { Membandingkan } \\
\text { data lokal dan global } \\
\text { serta menjelaskan } \\
\text { hubungan keduanya }\end{array}$ \\
\hline & \multicolumn{4}{|c|}{ Menggunakan data (reading beyond the data): } \\
\hline & $\begin{array}{l}\text { Memberikan respon } \\
\text { invalid ketika } \\
\text { diminta membuat } \\
\text { prediksi. }\end{array}$ & $\begin{array}{l}\text { Membuat prediksi } \\
\text { yang tidak jelas atau } \\
\text { tidak sesuai data. }\end{array}$ & $\begin{array}{l}\text { Menggunakan data } \\
\text { untuk membuat } \\
\text { prediksi yang masuk } \\
\text { akal. }\end{array}$ & $\begin{array}{l}\text { Menggunakan data } \\
\text { dan konteks untuk } \\
\text { membuat prediksi } \\
\text { secara konsisten. }\end{array}$ \\
\hline \multirow{6}{*}{$\begin{array}{l}\text { Pendidikan } \\
\text { Menengah }\end{array}$} & \multicolumn{4}{|c|}{ Membaca data (reading between the data): } \\
\hline & $\begin{array}{l}\text { Membuat perban- } \\
\text { dingan tidak tepat } \\
\text { dalam dan antar } \\
\text { kelompok data. }\end{array}$ & $\begin{array}{l}\text { Membuat satu } \\
\text { perbandingan tepat } \\
\text { dalam dan antar } \\
\text { kelompok data. }\end{array}$ & $\begin{array}{l}\text { Membuat perban- } \\
\text { dingan lokal atau } \\
\text { global dalam dan } \\
\text { antar kelompok data }\end{array}$ & $\begin{array}{l}\text { Membuat perban- } \\
\text { dingan lokal dan } \\
\text { global dalam dan } \\
\text { antar kelompok data }\end{array}$ \\
\hline & \multicolumn{4}{|c|}{ Menggunakan data (reading beyond the data): } \\
\hline & $\begin{array}{l}\text { Membuat inferensi } \\
\text { tidak berdasar data } \\
\text { atau berdasar infor- } \\
\text { masi tidak relevan. }\end{array}$ & $\begin{array}{l}\text { Membuat inferensi } \\
\text { berdasar sebagian } \\
\text { data; ada inferensi } \\
\text { yang masuk akal. }\end{array}$ & $\begin{array}{l}\text { Membuat inferensi } \\
\text { hanya berdasar data, } \\
\text { sebagian inferensi } \\
\text { masuk akal. }\end{array}$ & $\begin{array}{l}\text { Membuat inferensi } \\
\text { berdasarkan data } \\
\text { dan konteks. }\end{array}$ \\
\hline & \multicolumn{4}{|c|}{ Menggunakan penalaran proporsional (using proportional reasoning) } \\
\hline & $\begin{array}{l}\text { Tidak menggunakan } \\
\text { pemikiran relatif }\end{array}$ & $\begin{array}{l}\text { Menggunakan } \\
\text { pemikiran relatif } \\
\text { secara kualitatif }\end{array}$ & $\begin{array}{l}\text { Menggunakan } \\
\text { pemikiran relatif dan } \\
\text { proporsional secara } \\
\text { tidak lengkap. }\end{array}$ & $\begin{array}{l}\text { Menggunakan } \\
\text { pemikiran relatif dan } \\
\text { proporsional secara } \\
\text { lengkap. }\end{array}$ \\
\hline
\end{tabular}

Analisis data dilakukan dengan mendeskripsikan hasil pembacaan pada kurikulum dan buku teks matematika serta mengaitkannya dengan ketiga model kompetensi literasi statistika yang telah dikemukakan.

\section{HASIL DAN PEMBAHASAN}

Mengacu pada Peraturan Menteri Pendidikan dan Kebudayaan Republik Indonesia Nomor 37 Tahun 2018 terkait Kurikulum 2013, kompetensi terkait matematika diberikan dalam dua cara. Bagi siswa kelas I hingga III Sekolah Dasar, matematika menjadi salah satu bagian dari tema-tema pembelajaran. Adapun bagi siswa kelas IV Sekolah Dasar hingga kelas XII Sekolah Menengah Atas/sederajat, matematika diberikan sebagai satu mata pelajaran tersendiri. Secara khusus bagi siswa kelas X hingga XII Sekolah Menengah Atas/sederajat dengan minat Matematika dan Ilmu Pengetahuan Alam (MIPA), ditambahkan satu mata pelajaran matematika khusus sehingga terdapat dua mata pelajaran matematika yang berlainan. Oleh karena itu, pemaparan hasil dan pembahasan dalam penelitian ini dilakukan secara terpisah untuk masing-masing jenjang.

\section{Literasi Statistika pada Buku Matematika Sekolah Dasar (SD)}

Kompetensi dasar terkait literasi statistika dalam pelajaran matematika Kurikulum 2013 jenjang SD diberikan pada kelas III hingga kelas VI, sebagaimana tercantum dalam Tabel 3. Kompetensi dasar matematika di kelas III Sekolah Dasar (SD) masih terintegrasi dengan mata pelajaran lain dalam bentuk pembelajaran tematik. Penyelidikan lebih lanjut menunjukkan bahwa kompetensi ini terdapat dalam tema 8 yang diberikan di semester II, yakni Praja Muda Karana. Oleh karena itu, dilakukan pengamatan pada buku pelajaran Tematik Terpadu 8 kelas III SD "Praja Muda Karana”, yang disusun oleh Sonya Sinyayuri, S.Si. yang diterbitkan oleh Pusat Perbukuan 
Kementerian Pendidikan dan Kebudayaan RI (Jakarta) pada tahun 2018. Pengalaman belajar yang termuat pada buku ini antara lain:

1) Membaca data sederhana yang diperoleh dari proses membilang/mencacah.

2) Menyajikan data dalam bentuk tabel sederhana.

3) Membaca data dalam bentuk diagram batang sederhana.

4) Melengkapi gambar diagram batang sederhana untuk menyajikan data hasil membilang/mencacah.

Tabel 3. Sebaran Kompetensi Dasar terkait Literasi Statistika dalam Kurikulum Matematika SD

\begin{tabular}{|c|c|c|}
\hline Kelas & Kompetensi Pengetahuan & Kompetensi Keterampilan \\
\hline III & $\begin{array}{l}\text { 3.13 Menjelaskan data berkaitan dengan diri } \\
\text { peserta didik yang disajikan dalam diagram gam- } \\
\text { bar }\end{array}$ & $\begin{array}{l}\text { 4.13 Menyajikan data berkaitan dengan diri pe- } \\
\text { serta didik yang disajikan dalam diagram gambar }\end{array}$ \\
\hline IV & $\begin{array}{l}\text { 3.11 Menjelaskan data diri peserta didik dan } \\
\text { lingkungannya yang disajikan dalam bentuk dia- } \\
\text { gram batang }\end{array}$ & $\begin{array}{l}4.11 \text { Mengumpulkan data diri peserta didik dan } \\
\text { lingkungannya dan menyajikan dalam bentuk dia- } \\
\text { gram batang }\end{array}$ \\
\hline V & $\begin{array}{l}\text { 3.8 Menjelaskan penyajian data yang berkaitan } \\
\text { dengan diri peserta didik dan membandingkan } \\
\text { dengan data dari lingkungan sekitar dalam bentuk } \\
\text { daftar, tabel, diagram gambar (piktogram), dia- } \\
\text { gram batang, atau diagram garis }\end{array}$ & $\begin{array}{l}\text { 4.8 Mengorganisasikan dan menyajikan data yang } \\
\text { berkaitan dengan diri peserta didik dan memban- } \\
\text { dingkan dengan data dari lingkungan sekitar dalam } \\
\text { bentuk daftar, tabel, diagram gambar (piktogram), } \\
\text { diagram batang, atau diagram garis }\end{array}$ \\
\hline VI & $\begin{array}{l}\text { 3.8 Menjelaskan dan membandingkan modus, } \\
\text { median, dan mean dari data tunggal untuk me- } \\
\text { nentukan nilai mana yang paling tepat mewakili } \\
\text { data }\end{array}$ & $\begin{array}{l}\text { 4.8 Menyelesaikan masalah yang berkaitan de- } \\
\text { ngan modus, median, dan mean dari data tunggal } \\
\text { dalam penyelesaian masalah }\end{array}$ \\
\hline
\end{tabular}

Kompetensi dasar matematika di kelas IV SD telah terpisah dari pembelajaran tematik. Oleh karena itu, dipilih buku "Senang belajar Matematika" kelas IV karya Dr. Hobri, S.Pd., M.Pd., Dr. Susanto, M.Pd., Dr. Muhammad Syaifuddin, M.M., Anggraeny Endah Cahyanti, M.Pd., Hosnan, S.Pd., Dhika Elvira Maylistyana, M.Pd., dan Khoirotul Alfi Syahrinawati, S.Pd., yang diterbitkan oleh Pusat Perbukuan Kementerian Pendidikan dan Kebudayaan RI (Jakarta) pada tahun 2018. Dalam buku ini, kompetensi dasar 3.11 dan 4.11 termuat dalam bab 5, yang berjudul Statistika. Beberapa pengalaman belajar yang terdapat pada bab ini adalah sebagai berikut.

1) Mengetahui kegunaan Statistika.

2) Mengenal tokoh statistika John Graunt.

3) Menyajikan data dalam bentuk tabel dan menafsirkannya.

4) Mengidentifikasi bagian-bagian suatu diagram batang.

5) Menginterpretasi data yang disajikan dalam bentuk diagram batang.

6) Menyajikan data dalam bentuk diagram batang.

7) Melakukan proyek pengumpulan data (tempat lahir siswa) dan menyajikannya dalam bentuk diagram batang yang sesuai.

Buku “Senang Belajar Matematika" kelas V yang ditulis oleh Purnomosidi, M.Si., Wiyanto, M.Si., Safiroh, S.Fil.I., dan Ida Gantini, S.Pd., serta diterbitkan oleh Pusat Perbukuan Kementerian Pendidikan dan Kebudayaan RI (Jakarta) pada tahun 2018 menjabarkan kompetensi dasar 3.8 dan 4.8 pada bab 5 yang berjudul Pengumpulan dan Penyajian Data. Beberapa pengalaman belajar yang terdapat dalam bab ini antara lain:

1) Menyimak pengertian data, data pribadi, informasi, dan metode pengumpulan data.

2) Membedakan data primer dan data sekunder.

3) Melakukan pengumpulan data dengan beberapa metode, yakni tes, bertanya langsung (wawancara), isian singkat (angket/kuesioner), dan pengukuran langsung (observasi).

4) Memilih metode pengumpulan data yang sesuai dengan permasalahan yang diberikan.

5) Menafsirkan data dengan mengurutkan data terkecil hingga terbesar.

6) Menyusun tabel frekuensi sederhana berdasarkan data.

7) Membaca dan menafsirkan data dalam bentuk tabel.

8) Menyajikan data dalam bentuk diagram gambar (pictogram). 
9) Menyajikan data dalam bentuk diagram batang.

10) Menyajikan data dalam bentuk diagram garis.

11) Mengidentifikasi kesesuaian bentuk penyajian data dengan karakteristik data yang diberikan.

Untuk kelas VI, dilakukan pengamatan pada buku "Senang Belajar Matematika" terbitan Pusat Perbukuan Kementerian Pendidikan dan Kebudayaan RI (Jakarta) tahun 2017, yang disusun oleh Dr. Hobri, M.Pd., Dr. Susanto, M.Pd., Dr. Mohammad Syaifuddin, MM., Anggraeny Endah Cahyanti, M.Pd., Dhika Elvira Maylistiyana, S.Pd., dan Khoirotul Alfi Syahrinawati, S.Pd. Buku ini menyajikan kompetensi dasar 3.8 dan 4.8 pada bab 4 dengan judul Statistika. Beberapa pengalaman belajar yang termuat pada bab ini adalah sebagai berikut.

1) Mengenal tokoh statistika Gottfried Achenwall.

2) Mengidentifikasi pengertian modus, median, dan rata-rata (mean).

3) Menentukan nilai modus, median, dan rata-rata data tunggal.

4) Mengidentifikasi karakteristik data berdasarkan modus (satu modus, dua modus, tidak memiliki modus) dan median (memiliki/tidak memiliki median).

5) Menentukan nilai yang tepat mewakili data, antara mean, modus, dan median.

6) Menentukan nilai mean, modus, dan median berdasarkan data yang disajikan dalam bentuk diagram batang.

7) Mengenal pengertian ukuran tendensi sentral dan statistika deskriptif.

Berdasarkan uraian di atas, terlihat bahwa cukup banyak kompetensi literasi statistika yang diberikan dalam mata pelajaran matematika di tingkat Sekolah Dasar. Ditinjau dari aspek literasi statistika menurut Gal (2002), siswa lulusan Sekolah Dasar telah mengenal jenis-jenis data (primer dan sekunder), beberapa cara memperoleh data (wawancara, pengamatan, angket, dan observasi), mengenal dan menggunakan statistika deskriptif seperti ratarata, modus, dan median, hingga menyajikan data dalam bentuk grafik dan tabel. Adapun ditinjau dari model Watson dan Callingham (2003), materi pelajaran matematika tingkat Sekolah Dasar telah memungkinkan siswa mencapai tingkat literasi 1 (ideosinkratik) dan 2 (informal). Dari model perkembangan penalaran statistika Jones et al. (2000), siswa telah memiliki beberapa kemampuan untuk mendeskripsikan data, mengorganisasikan data dalam bentuk meringkas data menjadi nilai tengah, serta merepresentasikan data dalam bentuk diagram. Untuk kemampuan analisis dan interpretasi data, siswa belum dikenalkan pada pembandingan data konteks lokal dengan global maupun prediksi menggunakan data.

\begin{tabular}{|c|c|c|c|c|c|}
\hline \multicolumn{6}{|c|}{$\begin{array}{l}\text { Asyik } \\
\text { Bereksplorasi }\end{array}$} \\
\hline Merah & Biru & Kuning & Hijau & Biru & Hijau \\
\hline Merah & Merah & Hijau & Ungu & Hijau & Biru \\
\hline Merah & Biru & Kuning & Hitam & Ungu & Biru \\
\hline Hijau & Kuning & Hijau & Ungu & Hijau & Kuning \\
\hline Hijau & Hijau & Hijau & Hijau & Hijau & Biru \\
\hline \multicolumn{6}{|c|}{$\begin{array}{l}\text { Pertanyaan } \\
\text { a. Sajikan data di atas dalam bentuk tabel, diagram gambar, diagram batang, } \\
\text { dan diagram garis! } \\
\text { b. Menurutmu, sajian mana yang paling sesuai? Sajian mana yang tidak sesua }\end{array}$} \\
\hline
\end{tabular}
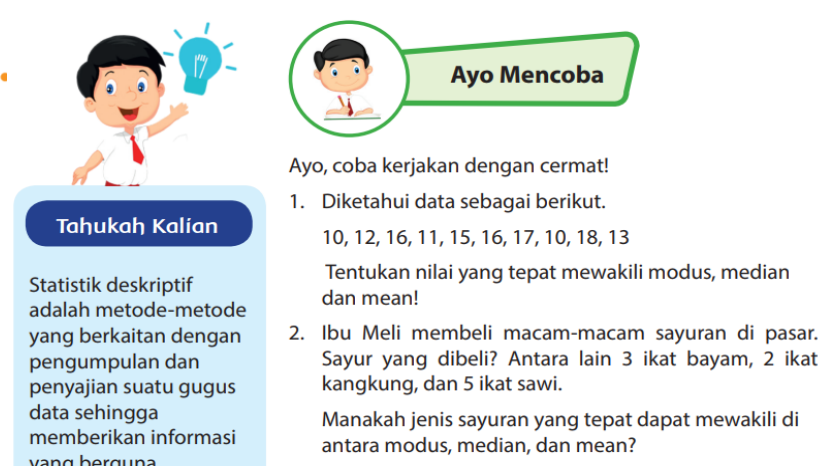

Gambar 1. Contoh Muatan Literasi Statistika pada Buku “Senang Belajar Matematika” Kelas V SD Halaman 245 (kiri) dan Kelas VI SD Halaman 188 (kanan).

Gambar 1 menunjukkan bahwa siswa kelas V SD telah diminta mengevaluasi efektivitas penyajian data secara grafis, yakni antara diagram gambar, diagram batang, dan diagram garis. Adapun di kelas VI SD, siswa diminta membandingkan penggunaan tiga macam ukuran memusat dari data, yakni modus, median, dan mean. Hal ini menunjukkan bahwa materi literasi statistika di tingkat sekolah dasar juga memuat keterampilan berpikir tingkat tinggi, yakni melakukan evaluasi dari hasil perhitungan maupun penyajian data.

\section{Literasi Statistika pada Buku Matematika Sekolah Menengah Pertama (SMP)}

Pada jenjang Sekolah Menengah Pertama (SMP)/Madrasah Tsanawiyah (MTs), kompetensi dasar terkait literasi statistika diberikan pada kelas VII semester II dan VIII semester II, sebagaimana tercantum dalam Tabel 4. 
Tabel 4. Sebaran Kompetensi Dasar terkait Literasi Statistika dalam Kurikulum Matematika SMP/Sederajat

\begin{tabular}{|c|c|c|}
\hline Kelas & Kompetensi Pengetahuan & Kompetensi Keterampilan \\
\hline VII & $\begin{array}{l}\text { 3.12 Menganalisis hubungan antara data dengan } \\
\text { cara penyajiannya (tabel, diagram garis, diagram } \\
\text { batang, dan diagram lingkaran). }\end{array}$ & $\begin{array}{l}\text { 4.12 Menyajikan dan menafsirkan data dalam } \\
\text { bentuk tabel, diagram garis, diagram batang, dan } \\
\text { diagram lingkaran. }\end{array}$ \\
\hline \multirow[t]{2}{*}{ VIII } & $\begin{array}{l}\text { 3.10 Menganalisis data berdasarkan distribusi da- } \\
\text { ta, nilai rata-rata, median, modus, dan sebaran } \\
\text { data untuk mengambil kesimpulan, membuat ke- } \\
\text { putusan, dan membuat prediksi. }\end{array}$ & $\begin{array}{l}\text { 4.10 Menyajikan dan menyelesaikan masalah yang } \\
\text { berkaitan dengan distribusi data, nilai rata-rata, } \\
\text { median, modus, dan sebaran data untuk mengam- } \\
\text { bil kesimpulan, membuat keputusan, dan mem- } \\
\text { buat prediksi. }\end{array}$ \\
\hline & $\begin{array}{l}\text { 3.11 Menjelaskan peluang empirik dan teoretik } \\
\text { suatu kejadian dari suatu percobaan. }\end{array}$ & $\begin{array}{l}\text { 4.11 Menyelesaikan masalah yang berkaitan de- } \\
\text { ngan peluang empirik dan teoretik suatu kejadian } \\
\text { dari suatu percobaan. }\end{array}$ \\
\hline
\end{tabular}

Buku teks matematika kelas VII Semester II terbitan Pusat Perbukuan Kementerian Pendidikan dan Kebudayaan RI (Jakarta) tahun 2018 ditulis oleh Dr. H. Abdur Rahman As'ari, M.Pd., M.A., Mohammad Tohir, S.Pd., Ibnu Taufiq, M.Pd., Erik Valentino, M.Pd., dan Zainul Imron, S.Pd. Dalam buku ini, kompetensi 3.12 dan 4.12 disajikan dalam bab 9 yang berjudul Penyajian Data, dan memuat beberapa pengalaman belajar di bawah ini.

1) Mengenal tokoh Statistika: Karl Pearson.

2) Memahami pengertian data dan datum, data primer, dan data sekunder.

3) Mendiskusikan cara-cara pengumpulan data (wawancara/interview, angket/kuesioner, dan observasi/ pengamatan) serta contoh penggunaannya.

4) Menyajikan data dalam bentuk tabel (tabel baris-kolom, tabel kontingensi, tabel distribusi frekuensi).

5) Mengolah dan menyajikan data dalam bentuk diagram batang.

6) Mengolah dan menyajikan data dalam bentuk diagram garis.

7) Menyajikan data dalam bentuk diagram lingkaran.

8) Menentukan jenis diagram yang tepat (batang/garis/lingkaran) untuk contoh data yang diberikan.

9) Menyusun proyek pengumpulan, pengolahan, penyajian, dan analisis data.

Buku teks Matematika kelas VIII yang diamati adalah karya Dr. H. Abdur Rahman As'ari, M.Pd., M.A., Mohammad Tohir, S.Pd., Ibnu Taufiq, M.Pd., Erik Valentino, M.Pd., dan Zainul Imron, S.Pd., yang diterbitkan pada tahun 2017 oleh Pusat Perbukuan Kementerian Pendidikan dan Kebudayaan RI (Jakarta). Dalam buku ini, kompetensi dasar 3.10 dan 4.10 disajikan dalam bab 9 yang berjudul statistika, sedangkan kompetensi dasar 3.11 dan 4.11 dipaparkan dalam bab 10 yang berjudul Peluang. Dalam bab 9 diberikan pengalaman belajar berikut.

1) Mengenal tokoh statistika: Dr. Genichi Taguchi.

2) Menginterpretasi data yang disajikan dalam bentuk diagram lingkaran, batang, dan garis.

3) Menentukan nilai rata-rata dari suatu kumpulan data yang disajikan dalam bentuk uraian, tabel, dan diagram.

4) Meninjau pengaruh data ekstrim terhadap nilai rata-rata.

5) Menentukan nilai median dan modus dari suatu kumpulan data yang disajikan dalam bentuk uraian dan tabel frekuensi.

6) Membandingkan nilai mean, median, dan modus dari suatu kumpulan data.

7) Menentukan ukuran penyebaran data (jangkauan, kuartil bawah, median, kuartil atas, dan jangkauan interkuartil).

8) Melakukan survei sederhana (terkait perilaku siswa menonton TV) yang terdiri dari tiga set data, yakni data jenis acara TV favorit, data lama siswa menonton TV, serta data lama siswa belajar mandiri di luar jam sekolah.

Adapun beberapa pengalaman belajar pada bab 10 terkait dengan dasar-dasar konsep probabilitas adalah sebagai berikut.

1) Mengenal tokoh probabilitas: Blaise Pascal.

2) Mengidentifikasi konsep peluang empirik melalui percobaan melempar dadu, koin, dan kelereng.

3) Mengidentifikasi percobaan yang bersifat acak (fair).

4) Mengklasifikasikan kemungkinan terjadinya suatu kejadian (mustahil, mungkin, atau pasti).

5) Menentukan frekuensi harapan dari suatu percobaan empirik.

6) Mengidentifikasi konsep peluang subjektif dan peluang teoretik atau peluang klasik. 
7) Menentukan nilai peluang teoritik.

8) Mengidentifikasi hubungan antara peluang empirik dan peluang teoretik.

Uraian di atas menunjukkan bahwa beberapa pengalaman belajar statistika yang termuat dalam buku teks matematika jenjang SMP merupakan pengulangan dari pengalaman belajar statistika di jenjang SD, misalnya terkait bentuk-bentuk penyajian data serta perhitungan ukuran tendensi sentral. Adapun beberapa pengalaman baru yang diperoleh pada jenjang SMP meliputi penyajian tiga macam tabel data (distribusi frekuensi, baris-kolom, serta kontingensi), penentuan ukuran sebaran data (jangkauan, kuartil, jangkauan interkuartil), serta praktik atau proyek sederhana yang melibatkan pengumpulan, pengolahan, penyajian, dan analisis data. Lebih lanjut, buku teks matematika kelas VIII SMP juga memberikan beberapa soal masalah pengambilan keputusan berdasarkan data, sebagaimana terlihat pada Gambar 2.

Buku teks matematika kelas VIII SMP juga telah memuat materi konsep probabilitas, mulai dari probabilitas empirik yang diperoleh melalui percobaan fair, hingga probabilitas klasik atau teoretik. Dalam pembahasan probabilitas empirik, buku ini juga memuat contoh-contoh hubungan antara data hasil observasi dengan probabilitas, seperti ditunjukkan pada Gambar 3. Hal ini memungkinkan guru menunjukkan hubungan antara konsep probabilitas dan statistika. Sebaliknya, dalam membahas konsep probabilitas teoretik, buku ini tidak memberikan contoh dalam bentuk kartu bridge.

10. Diagram berikut menunjukkan banyaknya sepatu olahraga yang terjual adalah ukuran 42

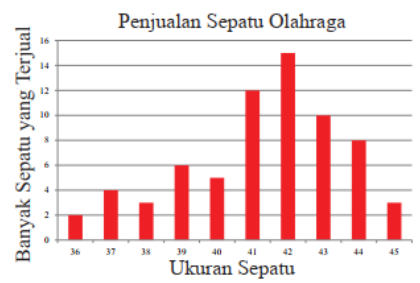

Dapatkan mean, median, dan modus dari data di atas. (untuk mea bulatkan sampai nilai satuan terdekat)

. Apakah pernyataan pemilik toko tersebut benar? Jika salah, coba kamu betulkan pernyataan pemilik toko tersebut.

Pada bulan September, pemilik toko ingin menambah stok sepatu olahraga ukuran tertentu yang paling banyak terjual pada bulan Selahra

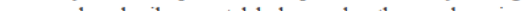
menggunakan hasil yang telah kamu dapakkan pada poin a, perhitungan manakah yang dapat membantu pemilik toko dalam menyelesaikan permasalahan tersebut? Apakah mean, median, atau modus? Jelaskan jawabanmu. di Toko Sepatu Mantap Jaya pada bulan Agustus berdasarkan ukuran

10. Andaikan kalian adalah manager TIMNAS INDONESIA U-19. Suatu ketika TIMNAS bertanding di Final piala ASIA melawan MALAYSIA. Suatu ketika saat pertandingan sedang berjalan, pada menit ke-89 TIMNAS mendapatkan hadiah PENALTI. Skor sementara adalah 2 - 2. Pemain yang siap menendang adalah EVAN DIMAS, ILHAM, MALDINI, dan MUCHLIS. Seandainya kamu disuruh untuk menentukan penendang penalti tersebut, siapakah yang akan kalian tunjuk agar TIMNAS meraih kemenangan? Berikut catatan tendangan penalti keempat pemain tersebut.

\begin{tabular}{|l|c|c|c|c|}
\hline \multicolumn{1}{|c|}{ Nama } & $\begin{array}{c}\text { Penalti } \\
\text { (kali) }\end{array}$ & Masuk & $\begin{array}{c}\text { Terblok } \\
\text { Kiper }\end{array}$ & Melenceng \\
\hline Evan Dimas & 20 & 16 & 2 & 2 \\
\hline Ilham & 18 & 14 & 2 & 2 \\
\hline Maldini & 17 & 12 & 4 & 1 \\
\hline Muchlis & 15 & 11 & 3 & 1 \\
\hline
\end{tabular}

Gambar 2. Contoh Soal Penggunaan Data dalam Pengambilan Keputusan pada Buku Siswa Matematika Kelas VIII SMP Semester 2 Hal. 255 (kiri) dan Hal. 300 (kanan).
7. Nunik melakukan percobaan pemutaran spinner dengan 4 warna yang tidak sama luas. Setelah melakukan percobaan sebanyak 25 kali didapatkan hasil sebagai berikut.

\begin{tabular}{|c|c|c|c|c|}
\hline Warna & Merah & Kuning & Hitam & Putih \\
\hline Banyak kali muncul & 5 & 10 & 7 & 3 \\
\hline
\end{tabular}

a. Perkirakan bagaimana spinner yang digunakan percobaan oleh Nunik.

b. Jika Nunik melakukan percobaan sebanyak 100 kali, kira-kira berapakali jarum spinner menunjuk ke warna putih? Jelaskan.

Gambar 3. Contoh Muatan Data pada Pembahasan Probabilitas dalam Buku Siswa Matematika Kelas VIII SMP Semester 2 Hal. 280 (kiri) dan Hal. 299 (kanan).

Ditinjau dari sudut pandang literasi statistika menurut Gal (2002), materi dalam pelajaran matematika pada tingkat SMP/sederajat telah mencapai empat dari lima aspek, yakni mengenal jenis data dan cara memperoleh data, menggunakan statistika deskriptif dan menyajikan data, serta memahami konsep probabilitas sederhana. Terkait model Jones et al. (2000), materi aspek analisis dan interpretasi data telah ditambah dengan perbandingan data dari dua kelompok. Dalam hal mengorganisasikan data, terdapat tambahan materi terkait ukuran persebaran data yang meliputi jangkauan dan jangkauan antar kuartil. 


\section{Literasi Statistika pada Buku Matematika Sekolah Menengah Atas (SMA) Sederajat}

Kompetensi dasar terkait literasi statistika dalam kurikulum matematika SMA/sederajat tersebar dalam mata pelajaran matematika Wajib (SMA/SMK/MA/MAK) kelas XII serta matematika peminatan (SMA/MA peminatan matematika dan ilmu alam) kelas XII. Rincian kompetensi dasar tersebut dapat dilihat pada Tabel 5.

Tabel 5. Sebaran Kompetensi Dasar Terkait Literasi Statistika dalam Kurikulum Matematika Sekolah Menengah Atas/Sekolah Menengah Kejuruan

\begin{tabular}{lll}
\hline Kelas & Kompetensi Pengetahuan & Kompetensi Keterampilan \\
\hline XII & 3.2 Menentukan dan menganalisis ukuran pe- & 4.2 Menyelesaikan masalah yang berkaitan de- \\
(wajib) & musatan dan penyebaran data yang disajikan & ngan penyajian data hasil pengukuran dan penca- \\
& dalam bentuk tabel distribusi frekuensi dan his- & cahan dalam tabel distribusi frekuensi dan histo- \\
& togram & gram \\
& 3.3 Menganalisis aturan pencacahan (aturan & 4.3 Menyelesaikan masalah kontekstual yang ber- \\
& penjumlahan, aturan perkalian, permutasi, dan & kaitan dengan kaidah pencacahan (aturan penjum- \\
& kombinasi) melalui masalah kontekstual & lahan, aturan perkalian, permutasi, dan kombinasi) \\
& 3.4 Mendeskripsikan dan menentukan peluang & 4.4 Menyelesaikan masalah yang berkaitan de- \\
& kejadian majemuk (peluang kejadian-kejadian & ngan peluang kejadian majemuk (peluang, keja- \\
& saling bebas, saling lepas, dan kejadian bersya- & dian-kejadian saling bebas, saling lepas, dan \\
& rat) dari suatu percobaan acak & kejadian bersyarat) \\
\hline XII & 3.5 Menjelaskan dan menentukan distribusi pe- & 3.5 Menyelesaikan masalah berkaitan dengan dis- \\
(MIPA) & luang binomial berkaitan dengan fungsi peluang & tribusi peluang binomial suatu percobaan (acak) \\
& binomial & dan penarikan kesimpulannya \\
& 3.6 Menjelaskan karakteristik data berdistribusi & 4.6 Menyelesaikan masalah yang berkaitan de- \\
& normal yang berkaitan dengan data berdistri- & ngan distribusi normal dan penarikan kesimpulan- \\
& busi normal & nya \\
\hline
\end{tabular}

Dalam buku Matematika Wajib kelas XII karya Dr. Abdur Rahman As'ari, M.Pd., MA., Dahliatul Hasanah, S.Si., M.Math.Sc., Prof. Dr. Ipung Yuwono, M.S., M.Sc.,Latifah Mustofa Lestyanto, M.Pd., Lathiful Anwar, M.Sc., Dr. Makbul Muksar, M.Si., Nur Atikah, M.Si., Syaiful Hamzah Nasution, M.Pd., dan Drs. Tjang Daniel Chandra, Ph.D. dan diterbitkan oleh Pusat Perbukuan Kementerian Pendidikan dan Kebudayaan RI (Jakarta) pada tahun 2018, kompetensi dasar 3.2 dan 4.2 tercantum dalam bab 2 yang berjudul Statistika. Beberapa pengalaman belajar yang terdapat dalam bab tersebut antara lain:

1) Mengenal tokoh statistika Ronald A. Fisher.

2) Menyusun tabel distribusi frekuensi tunggal maupun berkelompok.

3) Menyajikan data dalam bentuk histogram, poligon frekuensi, dan ogive.

4) Mengidentifikasi adanya miskonsepsi dalam pemaknaan grafik (histogram).

5) Menghitung ukuran pemusatan data (rata-rata, modus, dan median) pada data berkelompok.

6) Mengenal adanya tiga macam rata-rata (rata-rata hitung, rata-rata geometrik, rata-rata harmonis).

7) Mengenal konsep parameter populasi dan statistik sampel.

8) Menghitung ukuran penyebaran data (simpangan rata-rata, ragam, simpangan baku) data berkelompok.

Kompetensi dasar 3.3, 4.3, 3.4, dan 4.4 saling berkaitan, sehingga dalam buku matematika kelas XII tersebut disatukan dalam satu bab yakni bab 3 . Beberapa pengalaman belajar dalam bab ini antara lain:

1) Mengenal tokoh probabilitas Girolamo Cardano.

2) Menggunakan aturan penjumlahan dan aturan perkalian untuk pengisian tempat.

3) Menentukan rumus permutasi, kombinasi, permutasi dengan beberapa unsur sama, permutasi siklis, beserta penerapannya.

4) Mengidentifikasi kejadian majemuk serta peluang kejadian saling lepas.

5) Menghitung peluang bersyarat.

Berdasarkan uraian di atas, terlihat bahwa kompetensi dasar 3.2 dan 3.3 merupakan pengembangan lebih lanjut dari materi statistika pada tingkat SMP. Dari segi penyajian representasi data, diperkenalkan penyajian data kelompok dalam bentuk tabel distribusi frekuensi, histogram, poligon frekuensi, dan ogive. Pembahasan terkait potensi miskonsepsi dalam penyajian histogram dapat dipandang sebagai bentuk evaluasi dari suatu sajian data 
berkelompok. Di sisi lain, ditemukan beberapa kelemahan dalam pemaparan materiStatistika pada buku ini. Dalam pembahasan mengenai ukuran pemusatan, tidak ada penjelasan apapun terkait cara menentukan nilai-nilai modus, median, dan rata-rata data berkelompok. Terkait ukuran persebaran data, konsep kuartil dan jangkauan interkuartil yang telah diberikan di jenjang SMP tidak dijumpai lagi dalam buku ini, baik untuk data tunggal maupun data kelompok. Selain itu, simpangan rata-rata, ragam, dan simpangan baku diperkenalkan dalam bentuk rumus pada data berkelompok, tanpa didahului penjelasannya untuk data tunggal. Pembahasan mengenai ragam dan simpangan baku juga tidak disertai dengan interpretasi atau pemaknaan nilainya. Demikian pula contoh-contoh yang disediakan guna menuntun siswa menemukan konsep simpangan rata-rata, simpangan baku, dan ragam (lihat Gambar 4) cenderung tidak praktis dan sukar dipahami.

\section{Gontoh Soal2.16}

Tiga puluh sepeda motor terpilih dites untuk mengetahui efisiensi bahan bakar dalam kilometer per liter. Distribrusi frekuensi yang didapatkan disajikan berikut ini.

\begin{tabular}{|c|c|}
\hline Kelas & Frekuensi \\
\hline $7,5-12,5$ & 3 \\
$12,5-17,5$ & 5 \\
$17,5-22.5$ & 15 \\
$22,5-27,5$ & 5 \\
$27,5-32,5$ & 2 \\
\hline
\end{tabular}

Dari distribusi di atas didapatkan simpangan rata-rata 3,5, simpangan baku sebesar 5,1 dan ragam sebesar 25,7

Gambar 4. Salah Satu Contoh Soal Penyebaran Data pada Buku Teks Matematika Kelas XII SMA (Hal. 69)

Terkait dengan kompetensi dasar 3.3, 3.4, 4.3, dan 4.4, pembahasan teori peluang dalam buku matematika kelas XII SMA merupakan lanjutan atau pendalaman dari konsep-konsep peluang pada jenjang SMP. Konsepkonsep baru yang diberikan adalah aturan pengisian tempat, peluang kejadian majemuk, dan peluang bersyarat. Sebagai catatan, dalam buku ini tidak dibahas perhitungan peluang dengan Teorema Bayes. Terkait matematika peminatan, Pusat Perbukuan Kementerian Pendidikan dan Kebudayaan Republik Indonesia tidak mengeluarkan buku teks pelajaran matematika peminatan. Oleh karena itu, dipilih buku teks matematika peminatan kelas XII SMA yang telah mendapatkan penilaian dan pengesahan melalui Keputusan Menteri Pendidikan dan Kebudayaan Republik Indonesia Nomor 148/P/2016 tentang Penetapan Judul Buku Teks Pelajaran Peminatan untuk SMA/MA.

Buku berjudul Buku Siswa Matematika SMA Kelompok Peminatan MIPA kelas XII karangan Sunardi, Slamet Waluyo, Sutrisna, dan Edi Prajitno, diterbitkan oleh Bumi Aksara tahun 2018, memuat kompetensi dasar 3.5 dan 4.5 pada bab VI (statistik inferensial) serta kompetensi dasar 3.6 dan 4.6 pada bab VII (distribusi normal). Beberapa pengalaman belajar yang dapat dijumpai dalam bab VI adalah:

1) Mengingat kembali pengertian peluang suatu kejadian.

2) Mendalami pengertian variabel acak diskret dan kontinu.

3) Menentukan distribusi peluang dan distribusi peluang kumulatif variabel acak diskret.

4) Mengenal dan menghitung peluang dengan distribusi binomial.

5) Mengenal dan menghitung peluang dengan distribusi Poisson.

6) Mengenal uji hipotesis, kesalahan dalam uji hipotesis, serta uji hipotesis binomial.

Dalam bab VII, buku ini memberikan beberapa pengalaman belajar berikut.

1) Mengenal konsep variabel acak kontinu dan distribusi peluang kontinu.

2) Menentukan fungsi distribusi kumulatif kontinu.

3) Mengenal pengertian distribusi normal dan ciri-cirinya.

4) Menentukan luas di bawah kurva normal dengan tabel distribusi normal baku.

5) Menghitung peluang distribusi normal.

6) Mengenal dan menerapkan distribusi " $t$ ".

7) Melakukan uji hipotesis untuk rata-rata (satu populasi).

8) Mengenal tokoh Carl Friederich Gauss. 
Sebagai pembanding, ditinjau buku kedua yang berjudul Matematika untuk Siswa SMA/MA kelas XII karya Marthen Kanginan, Hadi Nurdiansyah, dan Ghani Ahmad, yang diterbitkan oleh Yrama Widya (Jakarta) pada tahun 2016. Dalam buku ini, tidak terdapat materi distribusi Poisson, uji hipotesis binomial, serta distribusi " $t$ ". Sebaliknya, buku ini memuat materi pendekatan distribusi binomial menggunakan distribusi normal. Hal ini menunjukkan bahwa masing-masing buku pelajaran memberikan penekanan atau perincian yang berbeda terhadap kompetensi dasar yang sama.

Ditinjau dari sudut pandang literasi statistika menurut Gal (2002), materi statistika dalam mata pelajaran Matematika Wajib di atas telah mencapai empat dari lima aspek, yakni mengenal jenis data dan cara memperoleh data, menggunakan statistika deskriptif dan menyajikan data, serta memahami konsep probabilitas. Hanya terdapat pendalaman atau perluasan materi dari bahan yang diberikan untuk siswa jenjang Sekolah Menengah Pertama (SMP). Bila ditambah dengan materi statistika pada matematika peminatan, siswa dapat mengetahui cara melakukan inferensi statistika, sehingga kelima aspek telah dipenuhi. Demikian pula bila ditinjau dari model Perkembangan penalaran statistika menurut Jones et al. (2000), terlihat bahwa sebagian besar muatan literasi statistika telah termuat dalam buku pelajaran SMA.

Apabila dilihat dari model tingkatan literasi statistika oleh Watson dan Callingham (2003), materi literasi statistika yang termuat pada keseluruhan buku matematika tingkat SMA dapat digolongkan sebagai kategori konsisten non kritis (level 4), mengingat adanya berbagai aspek penggunaan istilah, pengenalan adanya variasi dalam konsep peluang, perhitungan statistika terkait rata-rata, peluang sederhana, dan sifat-sifat atau karakteristik grafik. Untuk mencapai kategori atau level yang lebih tinggi, diperlukan penajaman materi statistika khususnya pada pengajuan pertanyaan-pertanyaan kritis.

Pokok bahasan terkait inferensi atau pengambilan kesimpulan yang hanya dijumpai pada mata pelajaran matematika untuk peminatan MIPA dapat menimbulkan perbedaan pengetahuan statistika siswa SMA/MA peminatan MIPA dengan SMA/MA bidang peminatan lain atau dengan siswa SMK. Dalam dataran praktis, siswa SMA/MA bidang peminatan non MIPA atau siswa SMK sebaiknya juga memiliki pengetahuan terkait inferensi atau pengambilan kesimpulan berdasarkan prosedur statistika.

\section{Potensi Pengembangan Materi Literasi Statistika}

Pemaparan sebelumnya menunjukkan bahwa kompetensi literasi statistika telah dibangun melalui mata pelajaran matematika dari kelas III SD/sederajat hingga kelas XII SMA/sederajat. Pada sub bagian ini disajikan rangkuman dari sudut pandang kompetensi literasi statistika.

Tabel 6. Sebaran Muatan Literasi Statistika menurut Gal (2000) dalam Matematika Kurikulum 2013 Revisi

\begin{tabular}{|c|c|c|c|c|c|c|c|c|c|c|}
\hline \multirow{2}{*}{ Kompetensi } & \multicolumn{4}{|c|}{ Kelas (SD) } & \multicolumn{3}{|c|}{ Kelas (SMP) } & \multicolumn{3}{|c|}{ Kelas (SMA) } \\
\hline & III & IV & $\mathrm{V}$ & $\mathrm{VI}$ & VII & VIII & IX & $x$ & $\mathrm{XI}$ & $\mathrm{XII}$ \\
\hline $\begin{array}{l}\text { Mengetahui jenis data } \\
\text { dan berbagai cara } \\
\text { memperoleh data. }\end{array}$ & - & $\mathrm{V}$ & $\mathrm{V}$ & - & $\mathrm{V}$ & - & - & - & - & - \\
\hline $\begin{array}{l}\text { Mengenal istilah dan } \\
\text { statistika deskriptif. }\end{array}$ & - & - & - & $v$ & - & v & - & - & - & $v$ \\
\hline $\begin{array}{l}\text { Mengenal penyajian } \\
\text { grafik dan tabel. }\end{array}$ & $v$ & $v$ & v & - & $v$ & - & - & - & - & $v$ \\
\hline $\begin{array}{l}\text { Pemahaman konsep } \\
\text { dasar probabilitas. }\end{array}$ & - & - & - & - & - & v & - & - & - & $v$ \\
\hline $\begin{array}{l}\text { Memahami perolehan } \\
\text { simpulan/inferensi } \\
\text { statistika. }\end{array}$ & - & - & - & - & - & - & - & - & - & $\mathrm{V}^{*}$ \\
\hline
\end{tabular}

Keterangan: $\mathrm{V}=\mathrm{ada} /$ dikembangkan, ${ }^{*}=$ hanya untuk peminatan IPA

Dari Tabel 6, terlihat bahwa aspek penyajian data dalam bentuk grafik dan tabel menjadi pokok bahasan yang dikembangkan dalam semua jenjang, sedangkan aspek perolehan simpulan/inferensi statistika hanya diberikan di jenjang SMA khususnya untuk siswa dengan peminatan MIPA. Dari segi persebaran jenjang, selama tiga tahun dari kelas IX SMP hingga kelas XI SMA siswa tidak mendapatkan tambahan pengetahuan literasi statistika melalui mata 
pelajaran matematika di sekolah. Hal ini juga merupakan pertanyaan yang tidak dapat dijawab oleh peneliti. Bila melihat sebaran materi pendukung literasi statistika yang selalu muncul setiap jenjang dari kelas III SD hingga VIII SMP, alangkah baiknya bila materi tersebut juga dibahas pada jenjang kelas IX SMP, X SMA, atau XI SMA.

Guna menata ulang sebaran muatan literasi statistika, beberapa perubahan susunan materi berikut dapat dilakukan pada saat revisi kurikulum. Terkait cara memperoleh data, siswa jenjang SMA sudah dapat dikenalkan dengan konsep populasi dan sampel serta metode survei dengan pengambilan sampel dan perancangan percobaan sederhana. Siswa dapat mendiskusikan berbagai cara pengambilan sampel serta merancang pengumpulan data dari suatu percobaan. Untuk konsep statistika deskriptif, sinkronisasi materi perlu dilakukan terkait ukuran penyebaran data yang dibahas di jenjang SMP dan di jenjang SMA. Terkait konsep probabilitas, alokasi waktu yang lebih dapat digunakan untuk memberikan pendalaman misalnya terkait Teorema Bayes hingga sebaran variabel acak. Materi pengambilan simpulan/inferensi statistika menggunakan pendugaan dan uji hipotesis sederhana sebaiknya diberikan kepada seluruh siswa SMA/sederajat, yakni sebagai bagian dari mata pelajaran matematika wajib. Dengan cara ini, semua orang yang pernah menempuh pendidikan wajib belajar 12 tahun diharapkan dapat memiliki kelima kompetensi literasi statistika tersebut. Sebagai gantinya, siswa SMA/MA peminatan MIPA dapat memperdalam statistika dengan cara menganalisis data eksperimen sederhana dengan metode statistika yang sesuai. Untuk keperluan tersebut, dapat digunakan data eksperimen yang telah dilakukan dalam mata pelajaran MIPA lainnya, misalnya Biologi, Fisika, atau Kimia.

Terkait dengan kompetensi penalaran dan interpretasi data, dapat ditambahkan materi terkait jenis-jenis pola pada data deret waktu, kemencengan/distribusi data, serta beberapa istilah yang sering digunakan dalam dataran praktis, misalnya sampling error, quick count, dan sebagainya. Dari segi penyajian data, siswa juga dapat dikenalkan pada penyajian data lebih dari satu variabel (misalnya dengan diagram pencar/scatter plot) serta penyajian data berdistribusi geografis. Dengan cara ini, seluruh aspek analisis dan interpretasi data pada model perkembangan penalaran statistika menurut Jones et al. (2000) dapat dimuat dalam buku matematika SD hingga SMA. Sebagai pembanding, buku pelajaran ekonomi kelas III SMA Kurikulum 1994 karya Ritonga dkk. yang diterbitkan oleh Penerbit Erlangga pada tahun 1999 bahkan memuat pokok bahasan analisis korelasi dan regresi linear sederhana, suatu metode statistika yang saat ini umumnya diberikan di jenjang perguruan tinggi.

Konsep probabilitas atau peluang juga dapat diperkenalkan secara intuitif bagi peserta didik di jenjang sekolah dasar/sederajat. Fokus pengenalannya bukan pada perhitungan nilai peluang, melainkan pada ketidakpastian atau kebolehjadian (likelihood) suatu peristiwa. Peserta didik dapat dikenalkan pada perbedaan peristiwa yang pasti terjadi, mustahil terjadi, dan mungkin terjadi. Sebagai referensi, buku Handling Data - Ages 10-11 (untuk usia SD) karya Helen Glasspoole yang diterbitkan oleh Adam \& Charles Black pada tahun 2009 telah memuat pembahasan mengenai kemampuan probabilitas secara intuitif.

\section{Keterbatasan dan Implikasi}

Buku-buku pelajaran matematika dan buku pelajaran tematis yang dipergunakan dalam penelitian ini hanyalah satu dari sekian banyak buku pelajaran yang beredar di pasaran. Hasil pengamatan pada kedua buku teks matematika peminatan kelas XII SMA/sederajat menunjukkan bahwa terdapat perbedaan pengalaman belajar antara kedua buku tersebut, yang juga berimbas pada kedalaman materi. Penelitian ini belum dapat memberi jawaban apakah buku-buku teks pelajaran lain juga memberikan pengalaman belajar yang sama dengan bukubuku teks 'paket' terbitan Pusat Perbukuan Kementerian Pendidikan dan Kebudayaan RI. Diperlukan riset lebih lanjut untuk melihat sejauh mana kemampuan literasi Statistika didukung oleh pengalaman belajar pada setiap buku teks pelajaran pada setiap jenjang.

Penelitian ini masih dibatasi pada kompetensi dasar mata pelajaran matematika. Padahal, kemampuan membaca grafik dan mengolah data juga dapat dijumpai dalam mata pelajaran lain, misalnya Bahasa Indonesia dan IImu Pengetahuan Alam. Diperlukan penelitian lanjutan untuk mengidentifikasi sejauh mana mata pelajaran lain juga berkontribusi terhadap kemampuan literasi statistika. Perlu diidentifikasi pula potensi pengembangan kemampuan literasi statistika melalui mata pelajaran selain matematika pada masing-masing jenjang.

Buku pelajaran yang telah memuat kompetensi literasi statistika tidak selalu berarti bahwa peserta didik yang menggunakannya juga memiliki kompetensi tersebut. Oleh karena itu, penelitian lanjutan dapat dilakukan terhadap penguasaan kompetensi literasi statistika di berbagai jenjang pendidikan sesuai dengan kompetensi yang telah diberikan pada jenjang tersebut dan/atau jenjang sebelumnya. Dengan cara ini dapat diketahui pula sejauh mana peran guru yang menggunakan buku pelajaran tersebut dapat menyampaikan kompetensi literasi statistika 
kepada para peserta didik. Untuk itu, diperlukan instrumen pengukuran kompetensi literasi statistika yang valid dan reliabel pada masing-masing jenjang pendidikan. Hingga saat ini instrumen tersebut belum tersedia dalam bahasa Indonesia.

Mengingat pentingnya kemampuan literasi statistika bagi peserta didik, guru sebaiknya memastikan bahwa setiap pengalaman belajar terkait literasi statistika sebagaimana dijabarkan dalam artikel ini sungguh dapat dialami oleh setiap peserta didik. Demikian pula para penyusun buku teks pelajaran sekolah sebaiknya memperhatikan kedalaman aspek literasi statistika dalam buku-buku tersebut.

\section{SIMPULAN}

Berdasarkan data yang diperoleh dan dianalisis dalam penelitian ini, dapat disimpulkan bahwa sebagian besar aspek literasi statistika telah termuat dalam buku teks matematika Kurikulum 2013, khususnya pada kelas III SD (tema 8), kelas IV SD, kelas V SD, kelas VI SD, kelas VII SMP, kelas VIII SMP, dan kelas XII SMA. Hal ini dapat dilihat dari kedalaman pengalaman belajar, materi, hingga soal-soal latihan yang disajikan. Di sisi lain, kemampuan pengambilan kesimpulan atau inferensi statistika yang merupakan bagian penting dari literasi statistika hanya diberikan bagi siswa kelas XII SMA/sederajat yang memilih peminatan MIPA. Hal ini berarti bahwa tidak semua lulusan SMA/sederajat mengalami pembelajaran literasi statistika dengan kedalaman yang sama. Beberapa perubahan dapat dilakukan pada kurikulum maupun buku teks pelajaran Matematika guna meningkatkan kemampuan literasi statistika peserta didik. Penelitian lebih lanjut perlu dilakukan untuk mengetahui peran mata pelajaran selain matematika dalam pengembangan kemampuan literasi statistika di sekolah.

\section{DAFTAR PUSTAKA}

Ben-Zvi, D., \& Garfield, J. B. (Eds.). (2004). The challenge of developing statistical literacy, reasoning and thinking (pp. 3-16). Dordrecht, The Netherlands: Kluwer Academic Publishers.

Gal, I. (2002). Adults' statistical literacy: Meanings, components, responsibilities. International Statistical Review, 70(1), 1-25.

Gubbi, J., Buyya, R., Marusic, S., \& Palaniswami, M. (2013). Internet of Things (IoT): A vision, architectural elements, and future directions. Future Generation Computer Systems, 29(7), 1645-1660. doi: https://doi.org/10.1016/j.future.2013.01.010

Hafiyusholeh, M. (2015). Literasi statistik dan urgensinya bagi siswa. Wahana, 64(1), 1-8. doi: https://doi.org/10.36456/wahana.64.1.531.1-8

Howson, G. (1995). Mathematics textbooks: A comparative study of grade 8 texts (Vol. 3). Vancouver: Pacific Educational Press.

Jones, G. A., Thornton, C. A., Langrall, C. W., Mooney, E. S., Perry, B., \& Putt, I. J. (2000). A framework for characterizing children's statistical thinking. Mathematical thinking and learning, 2(4), 269-307.

Jones, G. A., \& Thornton, C. A. (2005). An overview of research into the teaching and learning of probability. In G. A. Jones (Ed.), Exploring probability in school (pp. 65-92). New York, NY: Springer.

Khan, N., Yaqoob, I., Hashem, I. A. T., Inayat, Z., Ali, M., Kamaleldin, W., \& Gani, A. (2014). Big data: Survey, technologies, opportunities, and challenges. The Scientific World Journal, Volume 2014, 1-18. doi: https://doi.org/10.1155/2014/712826

Kusmanto, H., Nishfani MZ, N., Akbar, R. O. (2017). Analisis tingkat kemampuan literasi statistik siswa SMA sederajat berdasarkan mutu sekolah. Procediamath, 1(1), 33-47. Retrieved from http://syekhnurjati.ac.id/jurnal/index.php/semnasmat/article/view/2020

Lee, I. (2017). Big data: Dimensions, evolution, impacts, and challenges. Business Horizons, 60(3), 293-303. doi: https://doi.org/10.1016/j.bushor.2017.01.004

Leedy, P. D., \& Ormrod, J. E. (2015). Practical research planning and design (11th ed.). Boston, MA: Pearson Education. 
Maryati, I., \& Priatna, N. (2018). Analisis kemampuan literasi statistis siswa Madrasah Tsanawiyah dalam materi statistika. Journal of Medives: Journal of Mathematics Education IKIP Veteran Semarang, 2(2), 205-212. doi: https://doi.org/10.31331/medives.v2i2.640

Macintyre, T., \& Hamilton, S. (2010). Mathematics learners and mathematics textbooks: A question of identity? Whose curriculum? Whose mathematics? The Curriculum Journal, 21(1), 3-23. doi: https://doi.org/10.1080/09585170903558224

Mooney, E. S. (2002). A framework for characterizing middle school students' statistical thinking. Mathematical Thinking and Learning, 4(1), 23-63. doi: https://doi.org/10.1207/S15327833MTL0401_2

Ramda, A. H. (2017). Analisis kesesuaian materi buku teks Kemendikbud matematika kelas VII dengan Kurikulum 2013. Pythagoras: Jurnal Pendidikan Matematika, 12(1), 12-22. doi: https://doi.org/10.21831/pg.v12i1.14057

Ridgway, J., Nicholson, J., \& McCusker, S. (2011). Developing statistical literacy in students and teachers. In C. Batanero, G. Burrill., \& C. Reading (Eds.), Teaching statistics in school mathematics-Challenges for teaching and teacher education (pp. 311-322). Dordrecht: Springer. doi: https://doi.org/10.1007/978-94-007-11310_30

Rizkianto, I., \& Santosa, R. H., (2017). Analisis buku matematika siswa SMP Kurikulum 2013. Mosharafa: Jurnal Pendidikan Matematika, 6(2), 229-236. doi: https://doi.org/10.31980/mosharafa.v6i2.310

Schield, M. (1999). Statistical literacy: Thinking critically about statistics. Of Significance: A Topical Journal of the Association of Public Data Users, 1(1), 15-20.

Schield, M. (2004). Statistical literacy curriculum design. IASE Curriculum Design Roundtable. Retrieved from http://www.statlit.org/pdf/2004SchieldlASE.pdf

Sharma, S., (2017). Definitions and models of statistical literacy: a literature review. Open Review of Educational Research, 4(1), 118-133. doi: https://doi.org/10.1080/23265507.2017.1354313

Tiro, M. A. (2018). Strategi Aksi Gerakan Nasional Literasi Statistika di Indonesia. Prosiding Seminar Nasional Variansi (Venue Artikulasi-Riset, Inovasi, Resonansi-Teori, dan Aplikasi Statistika). Retrieved from https://ojs.unm.ac.id/index.php/variansistatistika

Utari, T., \& Hartono, H. (2019). Muatan penalaran dan pembuktian matematis pada buku teks matematika SMA kelas X Kurikulum 2013.Jurnal Riset Pendidikan Matematika, 6(1), 1-13. doi: https://doi.org/10.21831/jrpm.v6i1.17002

Valverde, G. A., Bianchi, L. J., Wolfe, R. G., Schmidt, W. H., \& Houang, R. T. (2002). According to the book: Using TIMSS to investigate the translation of policy into practice through the world of textbooks. Dordrecht, Netherlands: Kluwer.

Watson, J., \& Callingham, R. (2003). Statistical literacy: A complex hierarchical construct. Statistics Education Research Journal, 2(2), 3-46.

Yaqoob, I., Hashem, I. A. T., Gani, A., Mokhtar, S., Ahmed, E., Anuar, N. B., and Vasilakos, A. V. (2016). Big data: From beginning to future. International Journal of Information Management, 36(6), 1231-1247. doi: https://doi.org/10.1016/j.jijinfomgt.2016.07.009

Yuniawatika, Y. (2018). Statistical literacy and its urgency for students. Proceedings of 3rd International Conference on Educational Management and Administration (CoEMA 2018). doi: https://doi.org/10.2991/coema18.2018.41

Waal-Montgomery, M. D. (2015). World's data volume to grow $40 \%$ per year \& 50 times by 2020: Aureus. Retrieved from https://e27.co/worlds-data-volume-to-grow-40-per-year-50-times-by-2020-aureus-20150115-2/

Wildani, J., Triyana, I. W., \& Mahmudah, W. (2019). Literasi statistis siswa kelas VIII SMP Negeri 1 Gresik. WYGOTSKY: Jurnal Pendidikan Matematika dan Matematika, 1(2), 99-110. doi: https://doi.org/10.30736/vj.v1i2.137 